\title{
Climate change and the mitigating tool of salvage archaeology: The case of the Fort Kongensten site at Ada Foah, Ghana
}

\author{
Victoria A. Aryee \\ Assistant Lecturer \\ Department of Archaeology and Heritage Studies \\ University of Ghana, Legon, Ghana. \\ Email: Vaaryee@ug.edu.gh \\ Wazi Apoh \\ Senior lecturer \\ Department of Archaeology and Heritage Studies \\ University of Ghana, Legon, Ghana. \\ Email:wapoh@ug.edu.gh
}

Submitted: April 24, 2018 / Accepted: October 24, 2018 / Published: November 30, 2018

\begin{abstract}
In the ongoing attempts at lessening the hydra-headed impacts of climate change, this paper explored the strategic use of salvage archaeology in the scientific retrieval and documentation of heritage remains and sites under the threat of climate change. In doing so, the research examined the effects of climate change and global warming on coastal heritage resources. Specifically, in Ghana, sea levels have been steadily rising over the centuries leading to the erosion of coastlines and the submergence of historic coastal settlements to about 110 metres inland. A historic Danish Fort Kongensten constructed in 1783 along the coast of Ada-Foah in Ghana, for example, has been totally eroded away by the rising sea water. This paper assesses how salvage archaeology was used to retrieve, document and conserve cultural materials associated with the fort. It also explored the extent to which salvage archaeology and anthropology can be used as tools in climate change mitigation projects in impacted zones.
\end{abstract}

Keywords: salvage archaeology, coastal heritage resources, climate change, Ada Foah, mitigation. 


\section{Introduction}

Although climate change is a global phenomenon that has been with humans since time immemorial, its increasing alarming proportion is now becoming a source of worry to all stakeholders. The scientific discourse on climate change often addresses issues of trend analysis and climate change modeling to foreground ongoing global impacts. However, the use of alternate approaches such as the salvage archaeology has been marginal in this discourse. Climate change impacts are being registered in local areas in the form of rising temperatures, melting of polar ice, rising sea levels, variations in the frequency and intensity of hurricane activity (Cooper \& Peros, 2010, p.1), as well as altered and erratic rainfall patterns (Rudiak-Gould, 2011, p.11). Furthermore, water bodies are at risk of drying up, and most areas of lush greenery run the risk of becoming unattractive in the long run. This ongoing global climatic phenomenon (Hulme 2009, p.322) is also taking its toll along the eastern coast of Ghana (Aryee, 2013). A study conducted by Sagoe-Addy and Addo indicates that sea levels will rise at an average of $3.3 \mathrm{~mm} /$ year, while the shoreline will erode by as much as $0.86 \mathrm{~m} /$ year. This research also predicts that the sea level along the shores of Ghana will rise by $10 \mathrm{~cm}, 23.4 \mathrm{~cm}$ and $39.4 \mathrm{~cm}$ for the years 2020, 2060 and 2100, respectively. By their prediction, a total of thirteen historical heritage tourism facilities on the shoreline of Ghana will be at risk. Presumably these heritage resources include the key coastal forts and castles such as Elmina and Cape Coast castles. It is also estimated that $31 \%$ of these tourism facilities will not physically survive the effects of sea level rise (Sagoe-Addy \& Addo, 2012, p.155). Another example is the erosion of important potential touristic coastal heritage resources at Keta (a town in the Volta Region of Ghana). More importantly, a large number of important monuments, ancient trade roads as well as the Danish Fort Kongensten on the eastern coastline of Ada Foah, have been gradually eroded by the ocean. Available records indicate that since the 1940's, the ocean along the coast of Ada Foah has advanced approximately to about 110 meters inland (DEME records). Living 
in a farming community, the people of Ada Foah are now adjusting their farming habits to adapt to the changing weather patterns.

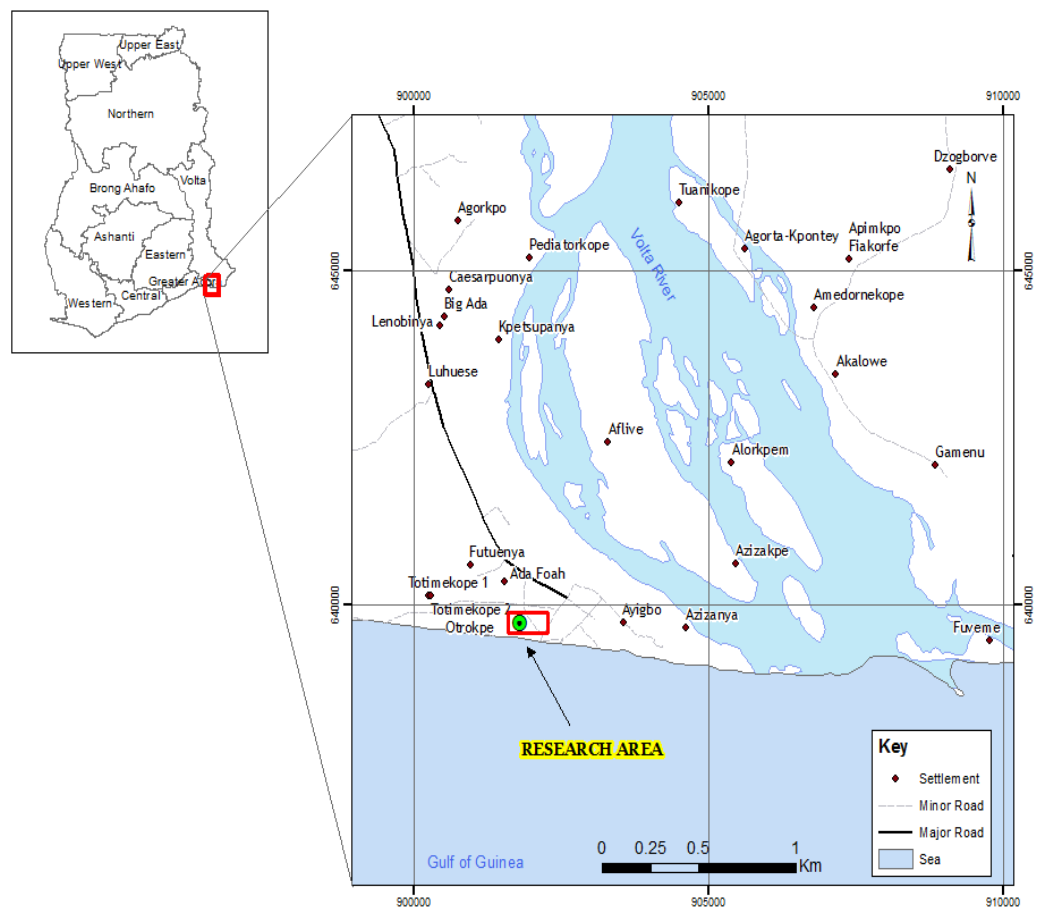

Figure 1: Map of Ada Foah research area

In more aggressive practical terms, a number of measures are being advanced and executed to mitigate the rate of eroding coastlines and their important plantations, settlements, and heritage resources. One of the key structural approaches involves the building of capital intensive rocky sea defense structures. Anthropological observations indicate that sea defense walls solve such negative impacts at one venue. However, the phenomenon tends to redirect its currents to cause havoc on other coastal shorelines (Oteng-Ababio et al, 2011, p. 430). Furthermore, the construction process of such sea defenses most often also leads to the destruction of remaining 
historical relics on such sites under the pretext of creating access roads. In the event that a sea defense structure cannot be built to preserve coastal heritage or if there is the need to destroy potential archaeological sites in some to make way for a sea defense structure, we advocate that salvage archaeology can be one of such effective mitigative tools.

What is known as salvage, development-led, preventive or commercial archaeology attests nowadays to the most widely practiced form of archaeology and CRM practices within Europe and the United States (Arazi, 2011, p.28). The practice seeks to salvage as much material culture as possible from archaeological sites under threat of either human-engineered situations or environmental disruptions; in this case, climate change and global warming. It can be used strategically to salvage, document and conserve important relics and coastline heritage resources. As a case study, this paper documents various aspects of a salvage archaeological project that was conducted at the former Fort Kongensten site of Ada Foah in Ghana. This approach was used to salvage remains at this historic coastal heritage site when the site was in the process of being totally destroyed to make way for the construction of a sea defense wall in the area.

\section{Addressing the effects of climate change on coastal heritage in Ghana.}

The cultural and natural heritage endowments in communities around the globe are not excluded from the effects of climate change. According to Neumann et al. (2000, p.3) "Climate change is likely to accelerate the historical rise in sea level through the warming of oceans and melting of ice, which in turn will affect coastal development, wetland resources, and recreation." The UNESCO World Heritage Center has enumerated a number of such climate change induced impacts on heritage resources. These include corrosion of historic monuments and traditional material cultures, erosion of archaeological sites and cultural landscapes as well as the interruption and termination of traditional lifeways (Collette, 2007; Rockman, 2015, p.38). In Africa for example, it has 
been noted that by the year 2020, between 75 and 250 million people are projected to be exposed to increased water stress...yields from rain-fed agriculture could be reduced by up to 50 percent in some regions, agricultural production, including access to food, may be severely compromised (Climate change synthesis report, 2007). Notably, a study on climate change and theatre for development conducted by Asiama in Axim (a town in the Western Region of Ghana) revealed that farmlands were under threat of inundation due to heavy rains occurring in what was previously their dry seasons (Asiama, Personal communication, 2012).

The key issue here is not the inevitable change, but how the change impacts society and how new strategic ways can be established to deal with such impacts.

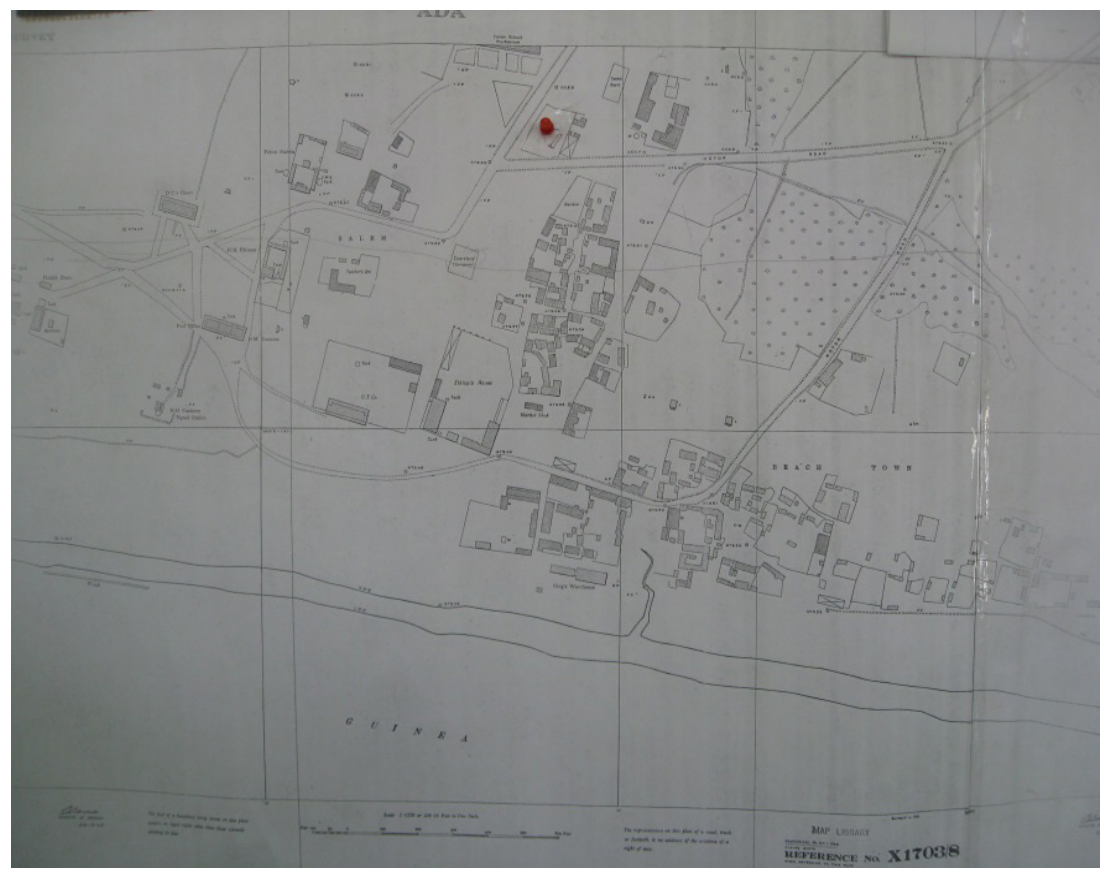

Figure 2: 20th century map of the Ada Foah coastline. Note the red pointer which marks the fort's previous location. The remaining area leading from the south to that marker has been eroded by the ocean (source: Dredging, Environmental and Marine Engineering) 
To enable the provision of a continuous monitoring of shorelines globally, remote sensing technology and the use of mapping techniques are being effectively used to identify, monitor and assess coastal changes in various places. The mapping methods adopt techniques that extract the shoreline positions from data sources such as historical maps, aerial photographs and repeated field measurements. These data are compared with current sources obtained from remote sensing technologies as well as airborne, space borne and land-based techniques. These mapping techniques enable information on the historic rate of change and estimated sea level rise for future shoreline positions to be estimated. The results obtained in 2011, for example, show that the global average rate of sea level rise for the past century was about 10 to $15 \mathrm{~cm}$ (Addo et al., 2011).

Expositions on the scientific and anthropological discourse on climate change (Strauss 2009, p.166) and the inimical local effects of this global environmental phenomenon (Byg \& Salick, 2009, p.156; Marino \& Schweitzer, 2009, p. 213), reveal how climate change anthropologists are focusing on ethnographic observation studies that look at local impacts of the global phenomenon and reception studies. Such studies tend to examine local views of climate change discourses and lived experiences. Environmental archaeologists and other scientists (Rockman, 2012, p.193) see the proposed Anthropocene as the current geological age which is characterized by the inimical impacts of the activities of human technological advances that are influencing such climatic and environmental perturbations. Increasing modernization, use of plastics and use of climate altering military armaments are the usual suspects in this regard (Revkin, 2015; Rockman, 2015, p. 42; Smith \& Zeder, 2013).

To better understand past evidences of the Anthropocene, Rockman (2015) presents the combinations of archaeological and historical and landscape analyses as a strategic way of outlining the range of impacts humans have had on the environment over the course of millennia. In this regard, "cultural resources have important 
information to add to the science of identifying and understanding the impacts and direction of climate change" (Rockman, 2015, p. 43). The archaeology of climate change (Cooper \& Peros, 2010) is a growing genre. Its proponents try to integrate "archaeology with ongoing geographical and environmental discussions of human responses to the effects of climate change and various mitigation strategies that have been or are being implemented to lessen its impacts (Cassar \& Pender, 2005).

\section{Reconnaissance survey: Background of the Fort Kongensten site}

Fort Kongensten site is located in Ada Foah a coastal town in the Greater Accra Region of Ghana. Ada serves as the capital of the Dangbe East District and can easily be referred to as one of the hubs of relaxation and tourism in the Greater Accra Region. During a reconnaissance survey of the Ada Foah area on Thursday 25th of April 2013, we noticed that plans were underway to demolish the remains of an 18th Century structure, Fort Kongensten, used as a prison. This was to make way for the construction of a much needed sea defense wall. The construction firm undertaking the sea defense project, Dredging, Environmental and Marine Engineering (DEME), was immediately contacted and they indicated that all administrative and traditional protocols had been adhered to and the demolition was to take place that very day. We suggested that the process for demolition be halted for a condition survey and possibly an excavation of the area to be conducted. This request was refused outright. This was because DEME project leaders had encountered and deliberated over several issues with the traditional council of Ada Foah throughout the year 2013. They claimed that there had been about four months delay on their construction activities due to the resistance of the traditional and religious rulers to the demolition of the forts' prison, considered to be an intrinsic part of their heritage.

This brings to the fore a number of issues bedeviling the conservation of heritage sites in Ghana. A review of the Antiquities Law (NLCD 387) and the Environmental Protection Agency 
regulations of Ghana, reveals that presently there is no law that compels contractors to consult with archaeologists before they embark on their construction and heritage destruction activities (Apoh et al., 2017). In this case, the destruction of this historic site came very late to the notice of the Department of Archaeology and Heritage Studies (DAHS) of the University of Ghana. As a result of this, there was no time to effectively document the monument or consider saving it. Deliberation with the DEME officials ended with the agreement that we could conduct an excavation after the demolition of the buildings. They agreed to grant us five working days to conduct salvage excavations on the project site as well as rummage through the debris on the site after which they would clear the site with heavy-duty machines. In the light of this, we had to conduct a salvage archaeological research to preserve and study as many material remains as possible.

Without a doubt, the sea defense wall is a necessary preventive mechanism for curbing sea erosion in Ada Foah. However, its construction came at a costly price that entailed the demolition of the priceless heritage remains of the people of Ada Foah. Evidently, the Fort Kongensten heritage monument that was once in existence at the site, had steadily been eroded by the ocean, leaving behind only the remnants of a concrete cistern; unfortunately, no archaeological work was done to record the details of the historic fort for the benefit of posterity before its total erosion.

The Ada Foah salvage archaeological project is worth highlighting here as one of the most recent salvage archaeological works conducted to mitigate the negative impact of rising ocean levels along the eastern shoreline of Ghana. The key research methods involved the integration of archival studies, ethnographic research and salvage excavations in the collection of data to understand the value of the impacted Fort Kongensten and associated abandoned colonial prison and school.

In the process, the archival research was conducted on Danish administrative documents and journals. The purpose of this 
was to have a steady foundation and historical back drop for the research. It also facilitated a better understanding of the nature of the Danish fort before it was washed away by rising ocean currents. In order to have an emic perspective of the culture of the people of Ada Foah, we undertook an ethnographic research. Interviews and focus group discussions were held in order to gather oral accounts and cultural information about the inhabitants. In locating informants, we first spoke to some of the youth in the community to know whether they had any idea about the fort or whether they had learnt about it in school. Their responses showed that they had no clear knowledge of the fort while it was in existence. In actual fact, they had been prohibited by the elders from swimming in the area where the fort once stood. The reason given was that periodically the sea waves brought to the shore dangerous building parts such as large stones, bricks, and more recently a concrete cistern. Based on the responses from the youth, we decided to target the elderly (above 45 years of age) in the community as key informants and this proved fruitful. During the excavation, we also seized the opportunity to interact with passersby and onlookers who were mostly women.

\section{Ethno-historical Account of the People of Ada Foah and Fort Kongensten}

The ethno-historical data gathered revealed that the people of Ada, like most southern Ghanaian ethnic groups, trace their ancestry to Western Sudan. They also link their migratory history to that of the popular narrative of King Agorkoli of Notsie and his cruelty. It is generally believed that his inordinate ruling led his subjects to create an ingenious escape plan which included the watering of the mud walls of Notsie until they gave way for them to escape out of the so-called agbogbome or fortification (Gayibor $\&$ Aguigah, 2005). This popular escape narrative has been heralded as a collective avenue for strengthening the bond that exists among people of Ewe origin. Greene (2002) asserts that this narrative is a German missionary orchestrated collective origin story for the Ewes. The history of the non-Ewe inhabitants of the fortification 
like the Ada and Ga-Adangbe people have been silenced in this missionary orchestrated grand Ewe origin narrative (Apoh, 2008)

According to the narrative given by the elders in the palace of the Ada paramount chief, the people of Ada were proclaimed by King Agorkoli as "Adawolawo" which means a wild, furious, brave and warlike people. Thus, the short version, 'Ada,' has stuck with them until today. According to the narrative the four Ada clans that migrated from Notsie led by a 'chief priest king' called Adi, were the Adibiawe, Lomobiawe, Tekperbiawe and Dangbebiawe clans. They were accompanied by the Ga-Adangbe people of Krobo, Osudoku and the Shai. These clans crossed the Volta River mystically and settled at a place called Togologo. However, whilst there, conflicts arose among the Ada clans and the other groups of people. Adi refused to bury the differences between them and proclaimed in Ewe "Lolorvor" which means "the love cord binding us together is severed". This resulted in the Krobos moving on to settle at areas within the Accra Plains.

The Ada people continued their stay at Togologo which was interspersed with raids by Akan warriors which threatened their peaceful existence. In the light of this threat, a scouting group was created with a hunter from each of the four clans, to search for a new settlement. It was during this scouting that one of the hunters, 'Korley', shot and wounded a wild beast. The beast scurried away. However Korley followed it only to realize that the beast was a mystical female being. This female being, according to the narrative, was the spiritual custodian of the Songoor Lagoon (a popular ecotourist attraction and major salt producing lagoon in Ghana). She gave custody of the Songoor Lagoon and its surrounding area to the people of Ada on the terms that the Songoor Lagoon be held sacred and protected from mining and misuse. Presently, a section of the lagoon known as Yomo Lagoon (translated as the lagoon of the Old Woman) is considered sacred and off limit to all invasive activities. The locals consider this place the meeting point of spirits and nature. The remaining portion of the lagoon is, however, accessible for mining and fishing activities.

Secondly, he (Korley) was to remain faithful to her, and 
thirdly he was also to promise not to adorn himself or his family members with gold. Gold and salt are the two minerals obtained from the Songoor Lagoon. After these terms were agreed upon by Korley, he and the people of Ada settled at the Okor forest and were given custody of the Songoor Lagoon and its environs. Interestingly when the Ada forces became victorious after the 1826 Katamansu War, they exchanged their gold spoils, gained from the defeated Asantes, for food before marching back to base (Apoh, 2001; Apoh $\&$ Gavua, 2010). This was probably because of their covenant with the mystical lady of the Songoor Lagoon. By undergoing the main Dangbe ritual of circumcision, other clans were assimilated into the Dangbe group in the Okor forest overtime. These migrant clans are the Kabiawe (Akan group), Kudzragbe, Korgor, Ohuewem and Koreabor. The Ada people are ruled by priest-kings.

By the mid-seventeenth century, the Danes had set up outposts on the shores of the Gold coast. However, these outposts were not successful until the latter part of the seventeenth century when they established more substantial outposts (DeCorse, 1993, p.155). Specifically, in 1783 the Kongensten Fort was established by the Danes in Ada for trading and as a defense post. It was mainly built to protect Danish trade against African attack (Van Dantzig, 1980, p.58). Fort Kongensten was later used as a slave trading post. According to oral accounts, the word 'Fort' was corrupted into 'Foah', hence the name 'Ada Foah'. In mid-nineteenth century, the fort was sold to the British. Since then it degraded over time. Fort Kongensten survived until the mid-twentieth century when it was washed away by tidal waves from the ocean. Towards the east of the fort site is an abandoned colonial primary school.

The school has also undergone a partial demolition, with parts of the foundation stripped off and pulled off to make way for the construction of a sea defense wall on the site. Governor Edward Carstensen whilst traveling the Coast of Guinea in 18421850 recorded in his journal that:

I spent the night in the ruins of the previous Fort Kongensten...Fort Kongensten consisted of four 
bastions, connected by walls in a regular square. The western courtine supports the residences of the fort. They still have a roof, but windows and doors have disappeared. The north wall (towards the town) has fallen, and with it the adjoining fronts of the corresponding bastions. The parapet is missing in most places. According to the present state, the forts of Kongensten...must be considered subject to ceaseless and final destruction because of time and weather. (Carstensen, 2010, p.148)

Climate change is accompanied everywhere by other kinds of change in society (Barnes, 2013, p.541; Townsend, 2004). In the case of Ada Foah, it is reflected mainly in the inhabitants' subsistence and migration patterns. Due to the current environmental issues that the town faces, the inhabitants have restructured their subsistence by taking a keen interest in onion farming. Although the soil is sandy, they mix it with adequate portions of manure to enable them plant the onion crop. They have also been pressured to relocate from their coastal homes to other non- permanent structures. Indeed, the fort and other important heritage resources on the Ada coastline have been swallowed up by the rising sea levels. Through the ethnographic study, we noted that the memory of the fort among the people of Ada Foah was almost nonexistent. The youth, between 18-30 years, that we interviewed were not aware of the significance of the fort. The respondents above 50 years, however, had a fair knowledge about the fort. Though not an in-depth understanding, there was an awareness of its existence and the presence of the Europeans on their side of the coast. Thus, it appears the knowledge of heritage and its relevance to the people of Ada Foah are seemingly the preserve of the traditional council and not the totality of its inhabitants.

According to Little (2016, p, 140), "the creation and development of heritage areas raise [a] number of critical issues related to the ways that we understand, study and commemorate the past." This statement addresses the different perspectives of persons 
in the communities as well as the government on what should be done concerning heritage loss. For example, the government has funded the construction of a sea defense wall that will involve the destruction of the remains of the fort along the coast of Ada Foah. The Ada traditional council, however, recognized the fort as a part of their heritage and refused to accept the final destruction of its associated sites. Ethnographic data collected revealed that the inhabitants of the town were not pleased at the interruption in the construction of the sea defense wall, and they did not agree to the delay in work for traditional protocol to be observed. This is because they had witnessed the erosion of homes and roads; some people had also lost their source of livelihood. They were apprehensive of the resistance being put up by the traditional council and feared they would be forced to move inland as the sea continued to get closer.

The scenario that played out at Ada Foah before the site of the fort was destroyed is revealing. It shows that different constituencies of people hold different views on the meaning of heritage, the control of heritage, the participation of each group in heritage, the funding of the preservation of heritage and also the economic developmental contribution of heritage. In this scenario, there was tension between the locals; specifically the traditional authority, the district assembly, the DEME construction firm and the youth on the demolition of the last standing shreds of the fort. Each group had a different perspective on heritage preservation and conservation and the interpretation and sentimental value of heritage. Such instances of conflict concerning heritage and the environment must be prevented from happening in other areas along the coast. In a country where there are no laws that will compel constructors to conduct archaeological surveys, archaeologists must take the initiative. More importantly, there are many heritage sites along the coast with tourism potential and high socio-economic values that need to be protected against destruction (Sagoe-Addy \& Addo, 2012, p.163).

In the light of the fact that climatic change is impacting all 
aspects of human systems, including cultural heritage, there is a need to protect and ensure sustainable management of threatened sites. One unique method of mitigating the effects of climatic change (e.g. sea level rise) on coastal heritage resources is to conduct detailed archaeological or salvage archaeological research on the sites. This must involve the use of comprehensive descriptive techniques, visual documentation and mapping of the heritage resources. In areas where there is a need for the construction of a sea defense wall, salvage archaeology must be one of the best approaches to adopt in saving some of the remains at these endangered sites. In this regard, our research shows that salvage archaeology can still be effectively applied in areas where heritage is under dire threat of climate change impacts and where mitigation methods are being contested.

The practice of salvage archaeology is not new in archaeological approaches or in cultural resource management (CRM) practices. However, its use in the anthropological (Crate and Nuttal 2009) and archaeological investigations of climate change is in its infancy in Africa. The methodology of salvage archaeology has been applied in several countries under different circumstances in most cases during construction works. Projects associated with the discovery of the Arizona Highway project of 1964 (Hammack, 1973), the Ghana Volta Basin Research Project in 1971; the New York African Burial ground in 1989 (Blakey, 2010, p.525), the Ghana Bui Hydroelectric Dam salvage archaeology project (Gavua \& Apoh 2011; Apoh \& Gavua, 2016) and the Tamale Airport Expansion Project (Apoh, 2018) are key examples.

\section{The salvage archaeological process at the Fort Kongensten site}

IIn carrying out the heritage mitigation intervention at Ada Foah, salvage archaeological processes were adapted. The primary aim was to salvage possible archaeological heritage from the remains of the Fort Kongensten and associated abandoned colonial prison and school on the Ada Foah coastline. The primary objective was also to understand the dynamic impact of the rising sea level on coastal heritage and how the use of salvage archaeology can aid 
in aspects of heritage preservation. The secondary objective was to use this salvage approach as a form of public archaeology to educate the public about what to do at such heritage sites that are being threatened by inimical environmental forces. Since the site was being destroyed by both natural (sea level rise due to climate change) and cultural (construction of sea defense) means, salvage archaeology was the best approach to use in order to retrieve material remains in the shortest possible time to mitigate the dual impact on the heritage remains of the historic site.

The process began with a two-day surface survey on the site. This resulted in the location of surface scatter of historical materials (see figure 3) amid the remains of the fort on the coastline and the foundation of the colonial school situated to the north of the fort site

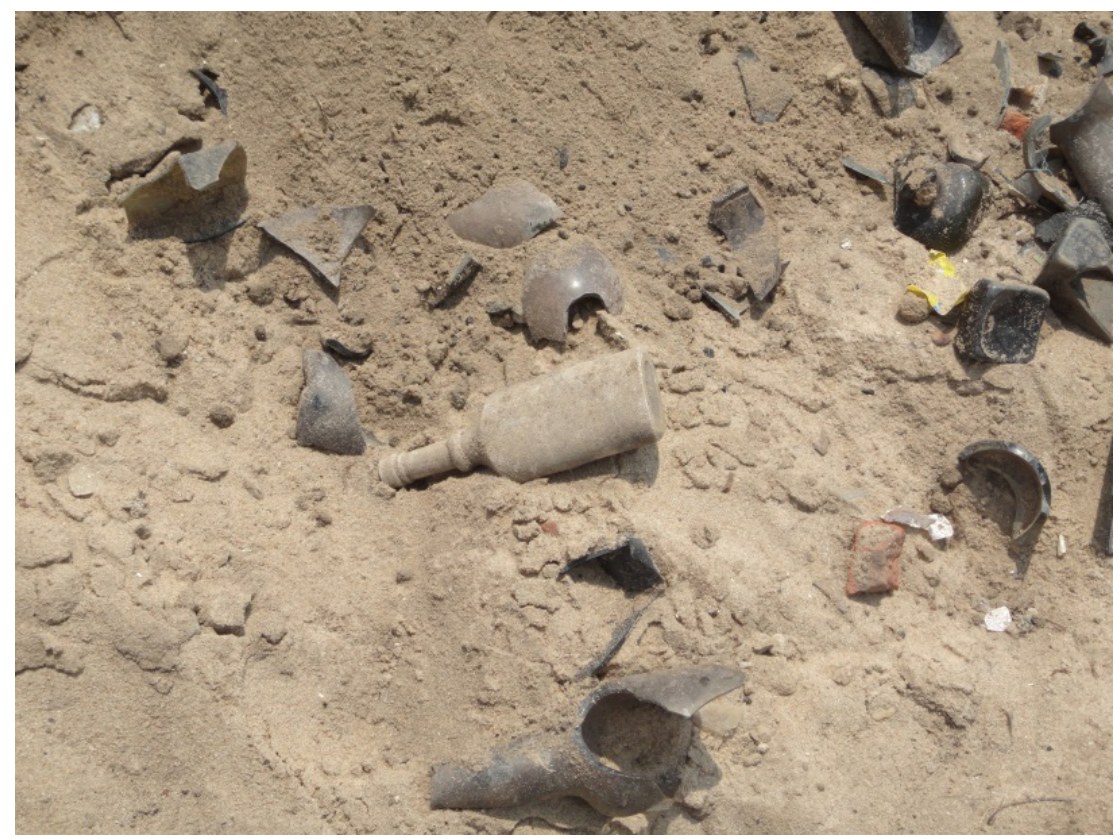

Figure 3: Surface scatter of archaeological remains

Unfortunately, the surface scatter was found on a limited piece of land. The relationship between the fort, the fort's prison and the colonial school is not yet certain. Their periods of existence vary extensively. The fort and its prison were in existence from an 
Aryee, V. A. and Apoh, W./ Climate change and the mitigating tool of salvage archaelogy earlier period in the eighteenth and early nineteenth centuries. The school, however, is a much later edifice built in the early twentieth century and abandoned in the 1970s. The surface cultural materials, e.g., fragments of bowls, plates, glass bottles and smoking pipes (Figure 4), recovered from the site indicate household materials which do not directly relate to formal education or school artefacts.

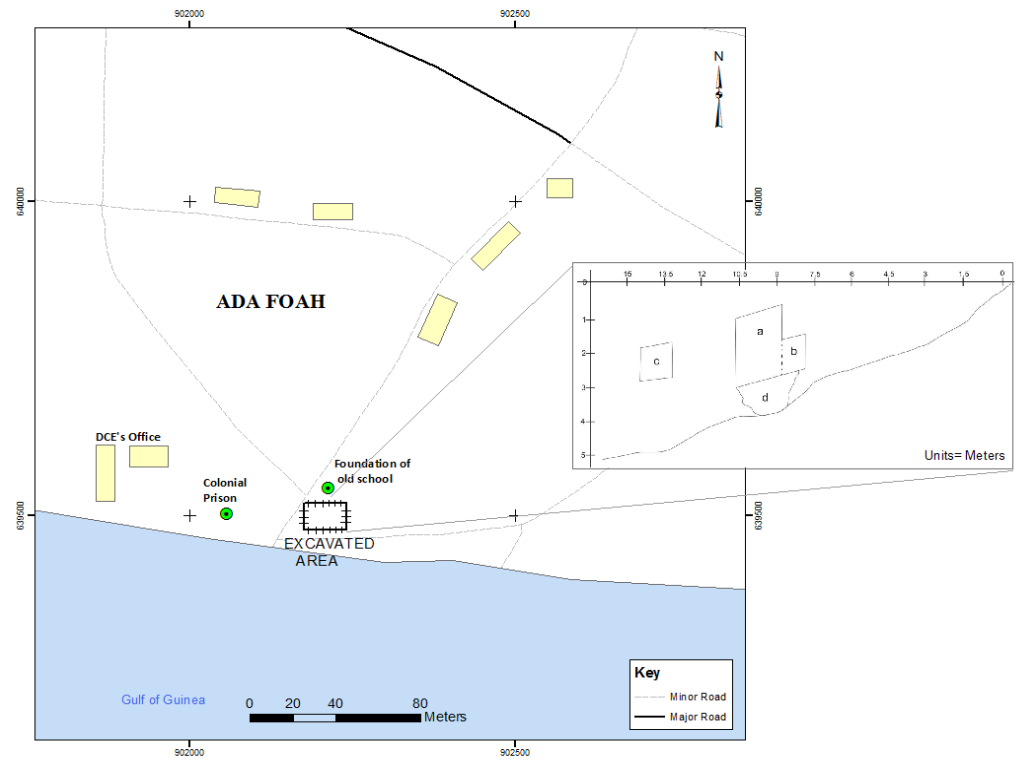

Figure 4: Map of work area

Based on the limited area we had to work with, we strategically excavated a $2 \mathrm{~m} 2$ unit using $20 \mathrm{~cm}$ intervals. Sterile level was encountered at a depth of $80 \mathrm{~cm}$ below datum. An analysis of the excavated area revealed a distinct outline of a midden feature in the south wall, characterized by a distinct rusted metal underlining (Figure 5). 


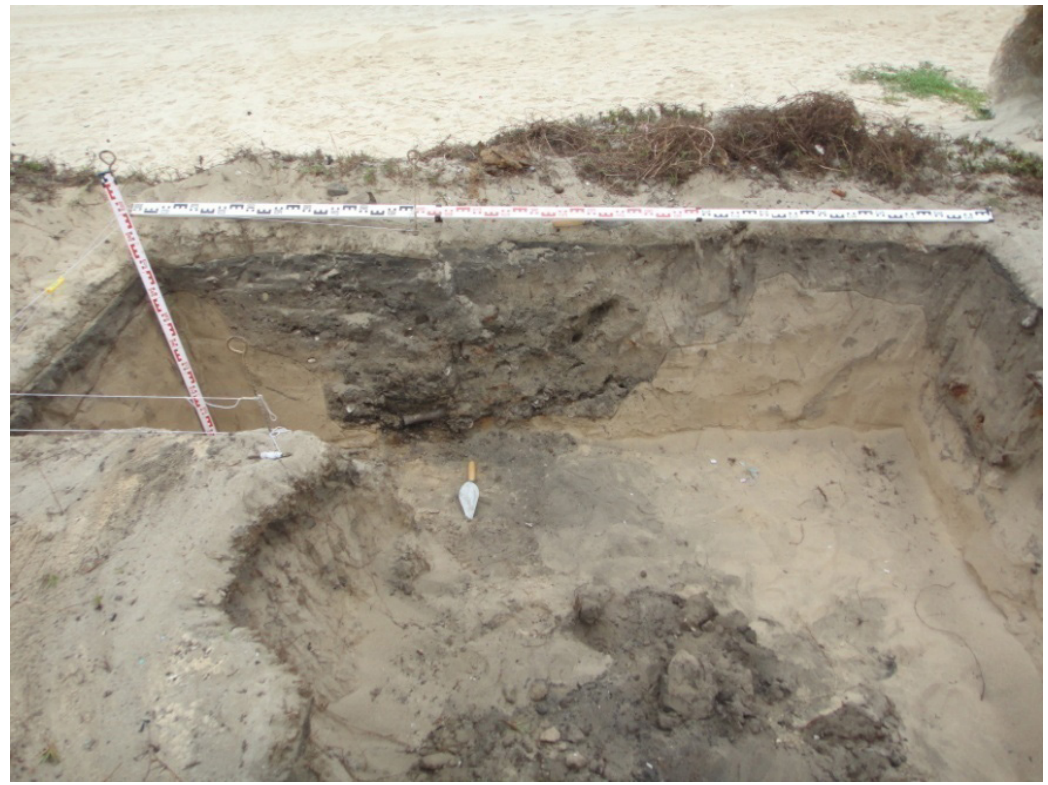

Figure 5: Photo of excavated unit two extension. Note the distinct markings on the southern wall, from which artifacts were retrieved

All artefacts recovered were from the feature. They included ceramics, shells, metal pieces, bottles, cowries, beads, local pottery, and smoking pipes. The soil color in the midden feature was dark sandy loam with specks of charcoal; as compared to the remainder of the unit which was mostly sandy. Due to the concentration of artefacts in the south wall we extended the unit into a $2 \times 3 \mathrm{~m}$ trench to recover similar kinds of artefacts. The third and fourth levels, however, revealed an increased amount of sea shells as well as a mix of charcoal pieces. Sterile level was also reached at $80 \mathrm{~cm}$ below datum.

The presence of the midden provides evidence of a discard practice among the people who once lived on the site. What is unclear is the specific agency involved in this discard practice. The midden is positioned in the center of three structures; the fort's prison, the fort itself and the colonial school. Thus, it could have been accessed by occupants of all of these three structures. However, based on ethnographic information, we established that 
since the school was built in the early 19th century and abandoned in the 1970s, its occupants might not be the agency involved in the use of the materials but rather, could have been involved in the making of the midden as a secondary form of discard.

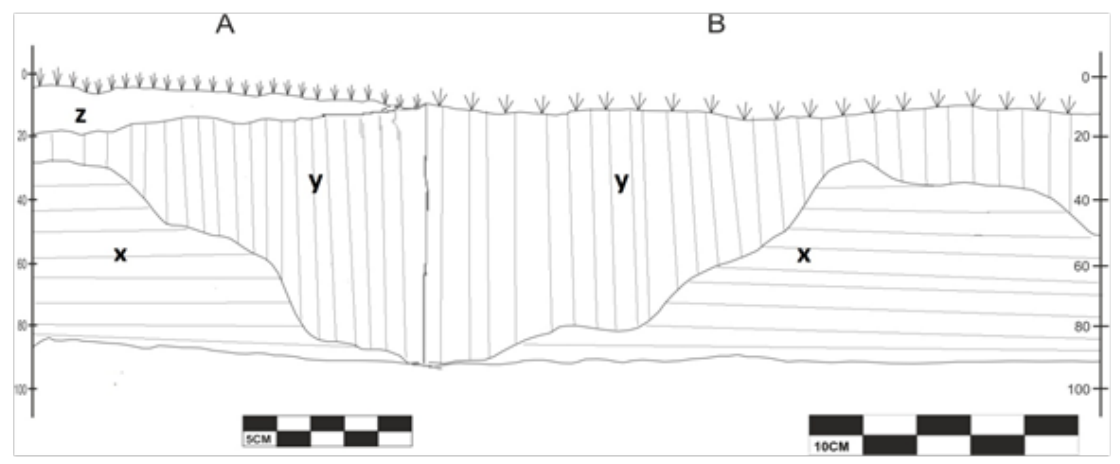

Figure 6: Juxtaposition of wall profiles from the south west quadrant of unit one and southeastern quadrant of unit two

\section{LEGEND:}

\begin{tabular}{|l|l|}
\hline $\mathbf{X}$ & $\begin{array}{l}\text { MIDDEN WITH METAL } \\
\text { OUTLINE }\end{array}$ \\
\hline $\mathbf{Y}$ & STERILE AREA \\
\hline $\mathbf{Z}$ & SANDY LOOSE SOIL \\
\hline
\end{tabular}

In the hope of revealing the entire midden we excavated the remaining portion of the unit towards the south (Figures 5 and 6). Excavation was done arbitrarily with a $20 \mathrm{~cm}$ interval to the sterile level of $74 \mathrm{~cm}$ below datum. Similar artefacts were also recovered. A $1 \mathrm{~m} 2$ unit was also excavated about ten meters to the east of the trench in order to test and explore the limited area for more associated data. Unfortunately, only a few material remains was recovered. They include ceramics, local pottery, metal, glass and shell. 


\section{Assessing the context and material remains of the salvaged site}

The feature excavated in the trench was approximately situated in the center point of three colonial structures which have all been demolished. They are Fort Kongensten, the Fort Kongensten prison and a colonial school. The rusted metal outline revealed in the wall profile of the excavated feature suggests that there was a metal container embedded in the ground for refuse collection. After close examination of the nature of the wall profile of the trench excavated, we concluded that the feature excavated is a midden. The salvage archaeological excavations revealed that the midden resulted out of a deliberate action taken by the earlier inhabitants of the area for appropriate refuse disposal in such a sandy environment. The majority of material culture recovered was from the midden.

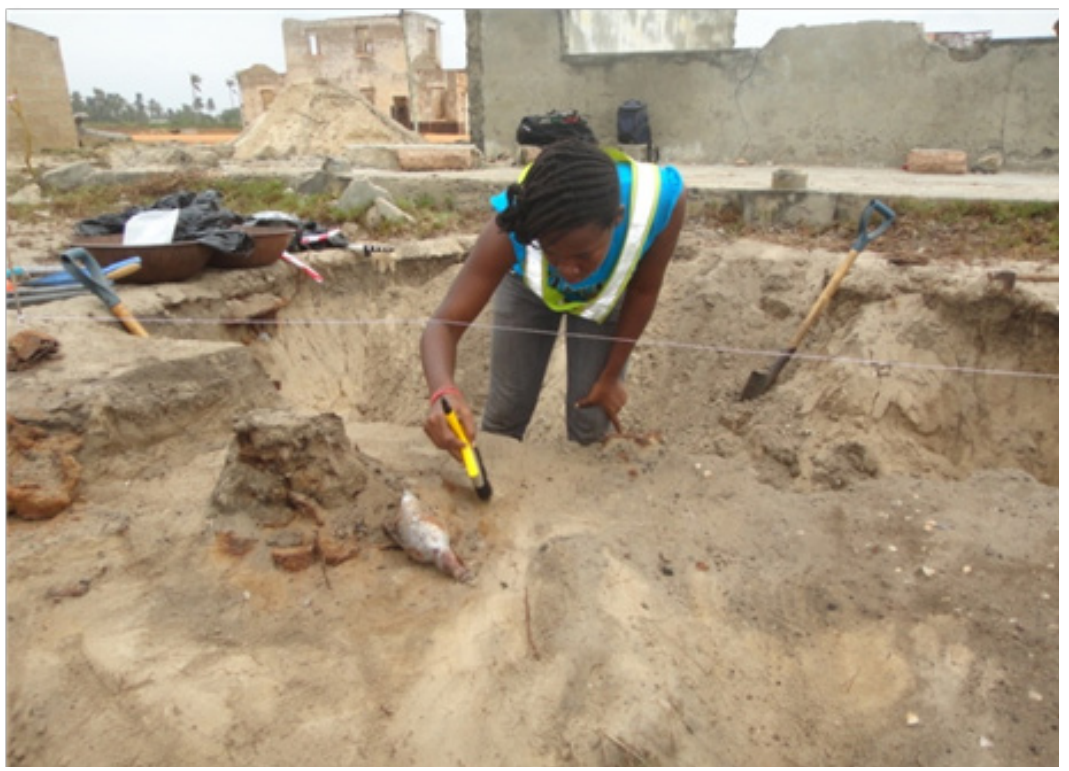

Figure 7: Unearthing the midden during the excavation

Analysis of the materials provided further insights into the lifeways on the site in the past. A total of 127 fragments of local pottery were recovered from the site and most of these had straight and everted rims. Such everted rims are unique to globular shallow 
bowls, which are typical nineteenth century pottery (BoachieAnsah, Personal communication, 2014). Methodical studies of these local pottery fragments revealed their decorative treatments and functions (see Figure 11). A total of 272 pieces of European ceramics were also recovered. This number forms $24 \%$ of the total assemblage of artefacts recovered. They were a mix of fragments of flat plates, deep bowls and soup plates. The assemblage is dominated by whitewares decorated with cut sponge designs. This technique is noted to have become common after about 1845 (DeCorse, 2001, p.157). The date range of the bulk of the excavated European ceramics is between the mid-eighteenth to twentieth centuries. This goes to support the view that the materials in the midden were likely utilised in the eighteenth century through to the twentieth century (see Figures 8 and 12).

Furthermore, none of the ceramic pieces had any form of makers mark on them. Mr. L.B Crossland (a ceramic expert; Personal communication 2014), came to the conclusion that the people of Ada Foah were receiving 'seconds products'. Seconds are flawed manufactured goods or factory rejects from Europe. He arrived at this conclusion based on his elaborate research which revealed that the eastern frontier of which Ada falls under was not a major trade point in European goods. Thus, the majority of materials that made their way to this area were factory rejects that had no 'maker's mark'/manufacturer's logo. Another likely reason for the lack of embossed goods could reflect the economic status of the Danes that settled along the eastern coastline. Flawed goods based on our findings could have been relatively cheaper to invest in for trading with some African indigenes as compared to goods of high quality.

A total of 260 pieces of glass fragments were recovered from the excavation. The diagnostic pieces were categorized into eight groups based on their primary functional properties. Notably, they may have served as vessels for mineral water, perfumery condiments, medications and alcoholic and non-alcoholic beverages (see Figure 13). The glass sherds are also parts of drinking glasses, 
cups and plates. Evidence of glass stoppers and closures were also found in the midden. It is also likely that these bottles were reused as containers (DeCorse, 2001, p.161). The presence of seals and embossments make it easier for bottle identification. Unfortunately, just a single seal was discovered during the excavations. This was a Blankenhyem and Nolet seal being an early eighteenth-century distillery apparatus from Schiedam, Netherlands. In addition to the sherd, there were significant whole pieces of Schnapps bottles, or "Dutch case gin" bottles. According to Mcnulty (1971), the case gin bottles had become unstable by $1780 / 1790$ leading to the refinement of the mold which ushered in the production of bottles with four pointed bases, instead of flat bottoms, to enable air circulation beneath the bottles

A total of 53 fragments of European kaolin pipes were discovered comprising 17 bowls and 36 stems (see Figure 10). Unfortunately, there were no significant decorations on them to make identification easy. There was, however, some form of incisions made on the bowls. According to Oswald (1975, p.96) decoration on bowls or stems is a considerable rarity in the seventeenth century since most of such decorations were initiated in the first half of the eighteenth century and became commonplace in the nineteenth century. There appears to be a general consensus that smoking pipes were introduced into Ghana and West Africa by the Portuguese. This data, however, is not based on solid evidence. It can also be attributed to the British, the Brandenburgers and the French as well (DeCorse, 2001, p.240). 
Aryee, V. A. and Apoh, W./ Climate change and the mitigating tool of salvage archaelogy

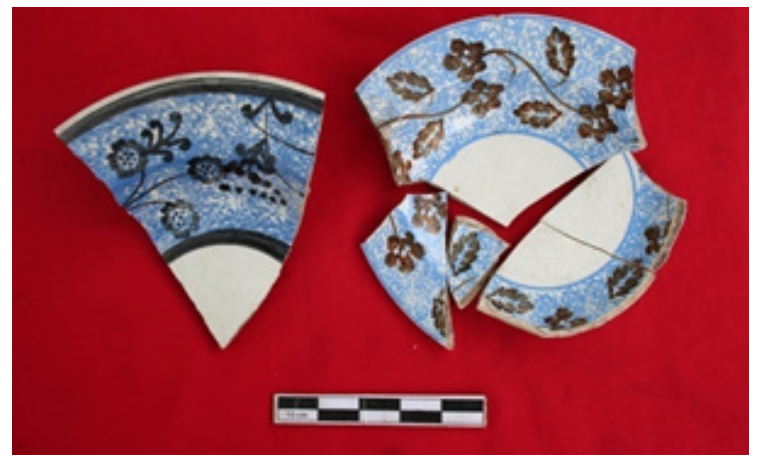

Figure 8: Photo of white ware with spatter and sponged decorations

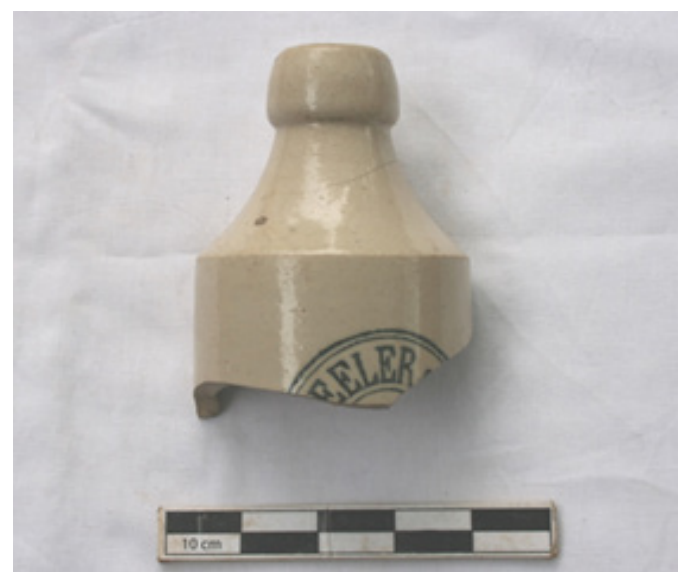

Figure 9: Photo of ginger stoneware bottle

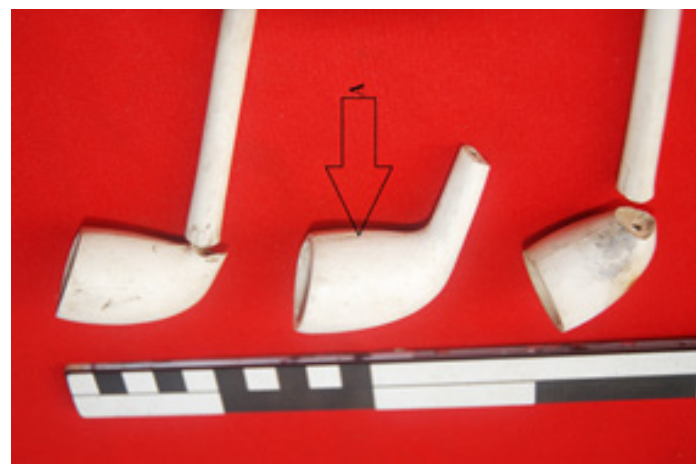

Figure 10: Photo of smoking pipes 
Aryee, V. A. and Apoh, W./ Legon Journal of the Humanities 29.2 (2018)

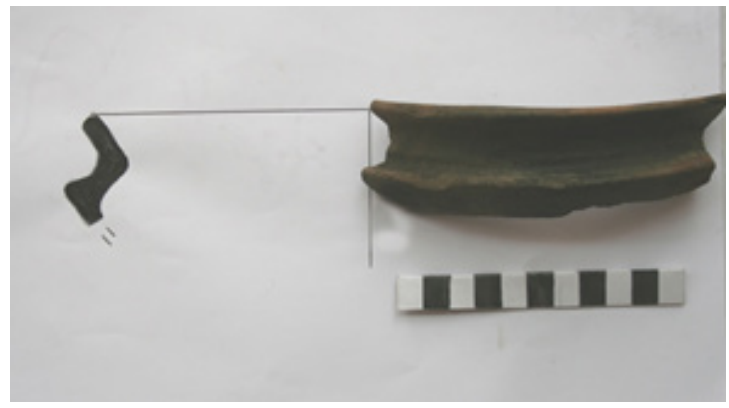

Figure 11: Profile of vertically everted rim of a shallow bowl

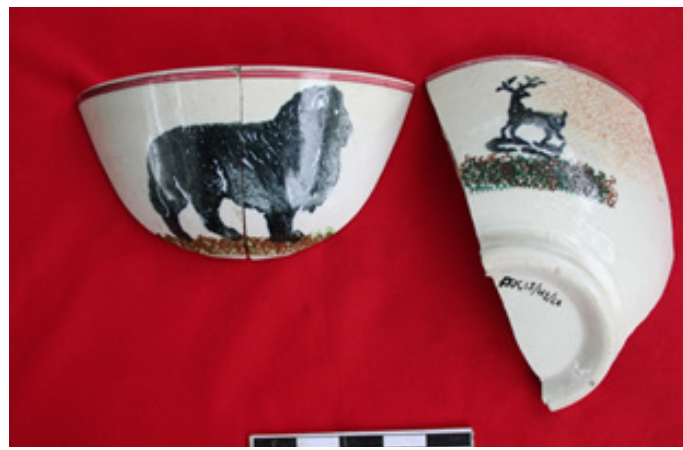

Figure 12: Photo of white wares with cut sponged decorations and spatter

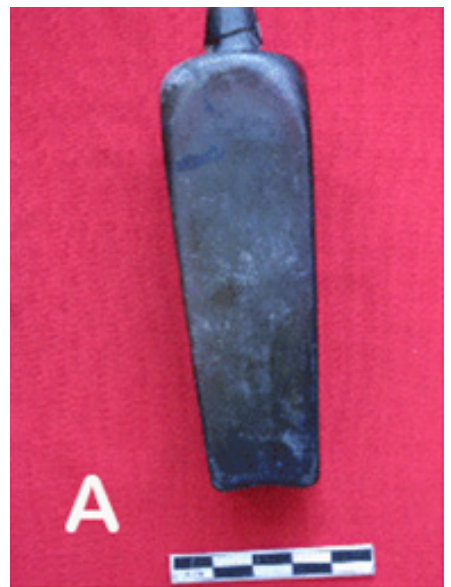

Figure 13: Dutch case gin bottle 
Other artefacts including cowries, beads, metal pieces and molluscs were recovered from the excavation. The people of Ada Foah have various uses for beads, such as for adornment, religious purposes and marking stages of life. The most significant function of beads is when it is used to mark stages of life. According to data gathered from the ethnographic research, a baby of eight days is adorned with beads, and at puberty a female child is required to wear beads for her rite of passage. The quality of beads represents the wealth of the family (Francis, 1993). The beads discovered from the excavation consisted of three plastic beads. These were polychrome (blue and yellow) spherically shaped beads with a hollow center. A total of forty-five pieces of cowry shells were discovered representing $4 \%$ of the total finds discovered. Only six could be clearly identified as belonging to the Cypraea moneta species. The remainder belonged to the Cypraea annulus species. These shells were probably used as currency, or for aesthetic purposes. A large number of Bivalvia shells were recovered from the excavation. These aquatic fauna remains belonged to two edible varieties; Arca senilis (locally known as "Adod3") and Ostreadenticulata (oysters). These fauna remains give an insight into the likely dietary pattern of the people who depended on ocean protein sources. The metallic finds from the site included both long and short nails. These appeared to be associated with construction practices.

After classification, analysis, and cross dating, the date range of the artefacts with the exception of the three pieces of plastic beads fell between the eighteenth and nineteenth centuries period. These dates corroborate historical data on the construction and habitation of the site: the Danes in the late eighteenth century (1783-1850), and the British (1850- n.d). The evidence of the beads, although minimal, suggests a possible continuous use of the feature in the early 20 th century. In total, the blend of "household" artefacts was $58 \%$ of artefacts recovered.

On this basis, we are inclined to suggest that the materials retrieved from the 'household' midden reflect the lifestyle of the 
Danes and the British on the coast. In the study of material culture, we conclude that the increased amount of European goods in the material culture recovered from the feature shows there was the need for such goods along the eastern coastline of the Gold Coast. They were either brought or used by the Danes and British on the site to support their lifestyle, or by the locals to mimic such western lifestyles of affluence. It is apparent that the lack of embossment on the goods was not a bother to the traders or the purchasers of the goods. The quality and quantity of the artefacts reflects the choices and taste of a section of the society that existed during that period on the site. With a high probability of the goods being 'seconds,' the society was probably not a high earning one. The ratio of European goods to local goods discovered in the excavations also suggests a dominance and high influence of European culture in that context. However, the associated indigenous pottery and fauna remains also reflect a form of cohabitation and a reciprocal influence of local lifeways on the Europeans on the site.

\section{Making salvage archaeology a strategic scientific and legal tool in mitigating heritage loss}

Considering the rapid transformation in Africa's infrastructure which can be attributed to widespread globalization, industrialization and modernization, coupled with the ongoing climate change impact on coastal heritage resources, there is the need for cultural heritage to be taken into consideration and preserved. For such comprehensive preservation to happen, salvage archaeology has to be part of legislations in African countries similar to CRM legislations and practices in Europe and the United States. Currently, South Africa (1999), Namibia (2004) and Botswana (2001), have overhauled their heritage legislations (Arazi, 2011, p.28; Ndoro, 2009, pp.26-28) to include international CRM legislations in the legal protection of cultural resources. Such CRM legislations recognize salvage archaeology as a strategic approach. Nevertheless, countries such as Zimbabwe, Zambia, Malawi and Tanzania have provisions in their legislations, as well as other statutes and policy provisions which when interpreted 
properly tend to serve a similar purpose of heritage preservation (Ndoro \& Kiriama, 2009, p.59).

In Ghana, however, legislative instruments on heritage research, conservation and promotion are limited. The Ghana National Museums Act of 1969, (NLCD 387) is the only legal binding legislation that encapsulates heritage resources in Ghana, however the clauses are antiquated and do not meet the exigencies of current times (Apoh et al., 2017). The act extensively defines antiquity and objects of 'archaeological' interest, by using the term 'archaeology' as the foundation for the definitions (see N.L.C.D 387 section 29). However, the act makes no mention of the use of an archaeologist to aid in the retrieval of 'antiquity' that has been discovered by a 'lay person' or the application of archaeological methodologies in protecting endangered sites. The law clearly outlines all the administrative processes that should take place in the case of a discovery, and it further outlines the duty of the board of the museum concerning the antiquity discovered. However, it falls short in protecting heritage (the antiquity) as a whole, because it does not include expert knowledge from archaeologists or salvage archaeology as a form of strategic cultural resource management practice (Fardin et al., 2016).

The World Bank, unlike the United States Agency for International Development (USAID) and the African Development Bank (ADB) (Brandt, 2000; MacEachern, 2001, p. 869), has in theory put in place operational policies that safeguard cultural resources. These policies are mandatory and are to be complied with by necessary agencies overseeing projects funded by the World Bank. Its most recent policy is the 'Operational Policy 4.11' which explicitly states that cultural resources must be a component of environmental assessment (Arazi, 2011, p.31). In this respect, the World Bank defines physical cultural resources as movable or immovable objects, site structures, groups of structures, and natural features and landscapes that have archaeological, paleontological, historical, architectural, religious, aesthetic, or other cultural significance; This definition encompasses not only human made resources, but also natural resources. The definition also states that 
physical cultural resources may be located in urban/rural settings, and may be above or below ground or underwater (World Bank Operational Manual OP 4.11- Physical Cultural Resources, 2006). Overall, this definition should ideally make it almost impossible for any cultural heritage in whatever form to be sidelined in an environmental impact assessment (EIA) and report for any World Bank sponsored project.

Notably, irrespective of the presence of these clear-cut international definitions and rigorous safeguard policies, there are still pertinent issues concerning non-compliance in Africa. Ideally, these issues have solutions yet on a more realistic note, the required CRM that should be done is absent. Arazi (2011, p.28) notes that "until effective in-country legislation and monitoring systems have been established, the confrontation on issues of noncompliance between the various stakeholders will remain a great challenge". Enforcing environmental and heritage impact assessment procedures in African countries is a must towards safeguarding archaeological cultural resources. Recent studies have shown that "18 African countries have EIA systems that they employ before the initiation of projects. Of these 18 countries, Ghana and Tunisia have functional and robust EIA systems" (Arazi, 2011, p.30). Although this is a good start for Ghanaian cultural resources, it should be noted that these EIA systems put in place by the Environmental Protection Agency (EPA), are environmentally biased. This is in the sense that, it appears the main concern of the EPA is on the study of the projects' impact on water bodies, wild life, forests, noise pollution among others. Experts from such disciplines are more readily contacted and placed on EIA teams whereas cultural heritage experts are usually excluded.

Irrespective of these legislative shortfalls in CRM enforcement, there has been a number of successful salvage archaeological researches conducted in Ghana. In most of these cases, the researchers/archaeologist had to take the initiative by petitioning and convincing the development companies involved to implement CRM and cultural heritage impact assessment projects 
on their construction sites. One of the most significant projects is the Volta Basin Research Project which was initiated after Ghana gained independence and has been ongoing until present. The salvage archaeological project was conducted over a $250 \times 250$ $\mathrm{km}^{2}$ of land that was to be inundated due to the construction of the Akosombo Hydroelectric Dam. Altogether more than 600 sites in the flooded area were surveyed and recorded prior to their inundation (Davies, 1971, p.3). More significantly, Acheulian and late Acheulian-Sangoan tools recovered from sites such as Mpeasem, Angeta, Yapei and Keta Krachi, have contributed greatly to the data on the Early Stone Age. In addition to that, several significant artefacts were recovered that contribute to the study of Middle Stone Age sites, as well as Neolithic and Iron Age industries in West Africa (Davies, 1971, pp.12-20). Over time, this project has opened up various avenues of on-going research in the Department of Archaeology and Heritage Studies, University of Ghana.

Furthermore, a salvage archaeological project was conducted at the Bui Hydroelectric Dam project site between 2009 and 2012 (Apoh et al., 2012; Apoh \& Gavua, 2016; Gavua \& Apoh, 2011). The "Kings City" salvage archaeological project in Asakai-Takoradi in the Western Region, and the 'City of Light' salvage archaeological project in Appolonia, located in the Greater Accra Region, were both completed in 2012 (Apoh, 2012a, b). Out of the four projects mentioned above, the Bui Dam project is the only one that has a video documentary that is periodically aired on national television (Documentary on the Bui Dam Salvage Archaeology Project 2013). This video aids in creating awareness about archaeological fieldwork and its relevance to the Ghanaian society. It also exemplifies the relevance of archaeology in documenting heritage resources before they are destroyed for other developmental projects.

\section{Conclusion}

Fortunately, the coast of Ada Foah has a sea defense wall now. However, if the government of Ghana does not embark on systematic mitigation projects, the case of the erosion of 
Fort Kongensten will reoccur on the coast of Osu and Nungua, suburbs in the Greater Accra Region. The question however is about sustainability. How do we maintain an environment that will not contribute to climate change? We are of the opinion that salvage archaeology when combined with other reception methods in anthropology will enable researchers to be fully armed and prepared for the worst-case scenario in any coastal community. Anthropological methodology when applied to research affords the researcher an insight into the lives of the community being studied, and this information can lead to a better understanding of climatic change impacts and thereby inform adaptation policy (Barnes \& Lahsen, 2013, p.541).

This brings us to the question of how to educate the Ghanaian populace on heritage in order to make archaeological research more meaningful. In our opinion, effective communication through public outreach is most likely the best approach to getting public archaeology done. Little (2016, p. 144), notes in her examination of issues on education and outreach that, "every sector of the archaeological profession considers public education and outreach to be important". What needs to be considered is the methodology and theoretical approach to getting effective communication done. In our opinion, effective communication involves education, the media and a clear understanding of issues. The world is fast becoming a global village, if not already one. Notably, information flows and networks have spread across borders in ways that could not be imagined before the onset of the internet, the global adoption of mobile telephony and social networks, and the rapid growth of broadband (Global information Report, 2013, p. 3). It has become necessary for the avenues of data sharing created by technology to be exploited by archaeology in aid of effective communication. These avenues are not likely to come without obstacles but overall, the advantages should outweigh the disadvantages. Information technology is a growing market and accessibility of information for the Ghanaian populace is key for recognition of the discipline.

Unfortunately, this research was limited in terms of site 
areas to work with thus restricting the material culture recovered. Nevertheless, with the data gathered, public archaeological methodology can be utilized to create awareness about the threat that coastal heritage faces. It is anticipated that the recent rise in sea level due to global warming will continue for centuries (Walkden \& Mills, 2008, p. 2). Thus, the future decline of the shoreline of Ghana will be greater than what has already taken place in the past. Most of the coastal inhabitants 'hope' that the rocks placed in the ocean (referral to sea defense wall) will hold the sea away for a while. Some also strongly doubt it. Anthropological and archaeological methods must be used in other coastal areas at risk of destruction such as Fort Patience at Apam and Ussher Fort in Accra.

It is, however, apparent that the discipline of archaeology has a long way to go to improve its public image in Ghana (Gavua, 2006). It is our opinion that archaeologists need to invest more effort into integrating public archaeology into their conventional archaeological practices to enhance its social benefits. Little (2016, p. 136) writes that "public archaeology also includes archaeologists' collaborations with and within communities, and their activities in support of civic engagement and civic renewal." What we gather from this statement is that public archaeology takes a step into social aspects to fulfill the social responsibility of the discipline. Based on this project, it becomes clear that salvage archaeology is a strategic approach in salvaging materials in climate change impact zones and other areas that stand the risk of losing their cultural/historical heritage. It is alarming to perceive what the future of the coast of Ghana will be in the next twenty years if conscious mitigation plans are not put in place. Thus, there is a need for archaeologists--whilst there is still time --to partner with related specialists such as earth scientists, climatologists and environmental experts to initiate welltailored mitigation methodologies. Such partnerships will be a true reflection of the eclectic nature of the discipline of archaeology and its relevance in conserving the past for use today and tomorrow. 


\section{References}

Addo, A. (2011). Impacts of coastal inundation due to climate change in a cluster of urban coastal communities in Ghana, West Africa. Remote Sensing, 3(12), 2029-2050.

Addo, A. K., Walkden, M., \& Mills, J. P. (2008). Detection, measurement and prediction of shoreline recession in Accra, Ghana. ISPRS Journal of Photogrammetry and Remote Sensing, 63(5), 543-558.

Amate, C. O. C. (1999). The making of Ada. Accra: Woeli Publishing. Apoh, W. (2008). The Akpinis and the echoes of German and British colonial overrule: An Archaeological investigation of Kpando, Ghana. ( $\mathrm{PhD}$ Thesis). Department of Anthropology, Binghamton University, NY, USA.

Apoh, W. (2012). Visual anthropological insights into the salvage archaeology and relocation of heritage remains at the Bui hydroelectric dam project site. Paper presented at the Society of Africanists Archaeologists (SAFA) Conference, Victoria University, Canada.

Apoh, W. (2012a). Final report for the Appolonia. City of Light Heritage Impact Assessment (CHIA) \& Salvage Archaeology. Appolonia Development Ltd:

Apoh, W. (2012b). Final report for the King City Cultural Heritage Impact Assessment (CHIA) \& Salvage Archaeology. Kings City Development Company Ltd:

Apoh, W. (2001). An archaeology of Katamansu: A battle site in the Accra plains of Ghana (MPhil Thesis). Department of Archaeology and Heritage Studies, University of Ghana.

Apoh, W. (2018). Final report for the salvage archaeology at the Airport Phase II Site. Ghana Airport Company Ltd

Apoh, W., \& Gavua, K. (2010). Material culture and indigenous spiritism: The Katamansu archaeological "Otutu" (Shrine). The African Archaeological Review, 27(3), 211-235.

Apoh, W., \& Gavua, K. (2016). "We will not relocate until our ancestors and shrines come with us", Heritage and conflict management in the Bui Dam Project Area, Ghana. In P. Schimdt, \& I. Pikirayi (Eds.), Community archaeology and heritage in Africa: Decolonising practice (pp. 204-249). London: Routledge.

Apoh, W., Wissing, W. K., Treasure, W., \& Fardin, J. (2017). Law, land and what lies beneath: exploring mining impacts on customary law and cultural heritage protection in Ghana and Western Australia. African Identities, 15(4), 367-389.

Arazi, N. (2011). Safeguarding archaeological cultural resources in Africa: Policies, methods and issues of (non) compliance. African Archaeological Review, 28(1), 27-38. 
Aryee, V. A. and Apoh, W./ Climate change and the mitigating tool of salvage archaelogy

Aryee, V. A. (2013). Salvage archaeology at the Fort Kongensten site of Ada Foah. (MPhil Thesis). Department of Archaeology and Heritage Studies, University of Ghana.

Asiama, R. (2012, February 8). Climate change and theatre for development. (V.A. Aryee, Interviewer)

Barnes, J., Dove, M., \& Lahsen, M. (2013). Contribution of anthropology to the study of climate change. Nature Climate Change, 3(6), 541-544.

Blakey, M. L. (2010). African burial ground project: Paradigm for cooperation? Museum International, 62(1-2), 61-68.

Boachie-Ansah, J. (2014, February 29). Analysing local pottery. (V. A. Aryee, Interviewer)

Byg, A., \& Jan, S. (2009). Local perspectives on a global phenomenonClimate change in eastern Tibetan villages. Global Environmental Change, 19(2), 156-166.

Carstensen, E. (2010). Closing the books. Governor Carstensen on Danish Guinea 1842-50. Accra: Sub-Saharan Publishers.

Casser, M., \& Robyn , P. (2005). The impact of climate change on cultural heritage:evidence and response. In I. Verger, The 14th Triennial Meeting The Hague Preprints (Vol. II, pp. 610-616). Maney-heritage.

Collette, A. (2007). Climate change and world heritage: Report on predicting and managing the impacts of climate change on world heritage and strategy to assist states parties to implement appropriate management responses (Vol. 22). World Heritage Report. Paris: UNESCO World Heritage Centre.

Cooper, J., \& Peros, M. (2010). The archaeology of climate change in the Caribbean. Journal of Archaeological Science, 37(6), 1226-1232.

Crate, S. A., \& Nuttal, M. (2009). Anthropology and Climate Change. Walnut Creek, CA: Left Coast Press.

Crossland, L. B. (2014, January-April). Analysing European ceramics. (V. A. Aryee, Interviewer)

Dantzig, V. A. (1980). Forts and Castles. Accra: Sedco Publishing Limited.

Davies, O. (1971). The Archaeology of the flooded Volta Basin. Occasional Papers in Archaeology(1), 5-21.

DeCorse, C. R. (1993). The Danes on the Gold Coast: Culture change and the European presence.The African Archaeological Review, 11(1), 149-173.

DeCorse, C. R. (2001). An Archaeology of Elmina,Africa and Europeans on the Gold Coast 1400-1900. Washington and London: Washinghton: Smithsonian Institution Press.

DeCorse, C. (2014). Historical Archaeology: Methods.meanings and ambiguities. In J. Anquandah, B. Kankpeyeng, \& W. Apoh (Eds.), Current Perspectives on the Archaeology of Ghana. A Department of Archaeology and Heritage Studies Reader (pp. 139-163). Accra: SubSaharan Publishers.

Fardin, J., Apoh, W., \& Wissing, K. (2016). From Mabo to Obuasi: Mining, heritage and customary law in Ghana and Western Australia. Journal 
of Energy \& Natural Resources Law, 34(2), 191-211.

Forum, W. E. (2013). The Global Information Technology Report: Growth and Jobs in a Hyperconnected World. Geneva. Retrieved from http://www. weforum.org/gitr

Francis, P. (1993). Where beads are loved. Lapis Route Books, Center for Bead Research.

Gavua, K., \& Apoh, R. W. (2011). Final report: Salvage Archaeology at the Bui dam project site,. Bui Power Authority, Ghana, Accra.

Gavua, K., \& Apoh, R. W. (Producers).(2011). Salvaging Cultural Heritage in the Bui Dam Project Area.[Motion Picture]. Ghana: Leventis Digital Resource Center.

Gavua, K., \& Nutor, K. (2014). Bringing Archaeology to the people:

Towards a viable public archaeology in Ghana. In J. Anquandah, B. Kankpeyeng, \& W. Apoh (Eds.), Current Perspectives on the Archaeology of Ghana. A Department of Archaeology and Heritage Studies Reader (pp. 264-275). Accra: Sub-Saharan Publishers.

Gayibor, N. L. (1977). Recueil Des Sources Orales du pays Aja-Ewe. Lome, Togo: Department d'histoire,University du Benin.

Gayibor, N. L., \& Aguigah, A. (2005). Early settlements and Archaeology of the Adja-Tado culture zone. In B. N. Lawrence, (Ed.), A Handbook of Eweland: The Ewe of Togo and Benin, (pp.1-13). Accra: Woeli Publishing Services,

Gibson, M. (2000). 19th Century Lustreware. Suffolk: Antique Collectors Club.

Greene, S. E. (2002). Sacred sites and the colonial encounter. Bloomington: Indiana University Press.

Group, W. B. (2014). World Bank Group. Retrieved from World Bank Group Website: http://www.worldbank.org

Hammack, L. C. (1973). Arizona highways salvage archaeology. KIVA , 39(2), 97-103.

Hulme, M. (2009). Why we disagree about Climate Change. Cambridge: Cambridge University Press.

Hume, N. I. (1976). A guide to artefacts of Colonial America NewYork: Knopf. IPCC. (2014, December 12). IPCC, 2007: Climate Change 2007: Synthesis Report. Contribution of Working Groups I, II and III to the Fourth Assessment. Retrieved from IPCC website: https://www.ipcc. $\mathrm{ch} /$ pdf/assessment-report/ar4/syr/ar4 syr full report.pdf

Little, B. J. (2016). Historical Archaeology: Why the past matters. Walnut Creek Calif.: Left Coast Press

Marino, E., \& Schweitzer, P. (2016). Talking and not talking about climate change in Northwestern Alaska. In S. A. Crate, \& M. Nuttal (Eds.), Anthropology and Climate Change: From encounters to actions. (pp. 209-217). London \&NewYork: Routledge Taylor \& Francis.

McNulty, R. H. (1971). Common beverage bottles: Their production, use and forms in seventeenth and eighteenth century Netherlands. Journal of Glass Studies, XII, 91-119. 
National Liberation Council. (1969, September 8th). NLCD 387. National Museums Act 1969. Accra, Ghana: Gazette.

Ndoro, W. (2009). Legal definitions of heritage. ICCROM Conservation Studies (8th edition), 25-35.

Ndoro, W., \& Kiriama, H. (2009). Management mechanisms in heritage legislation. In W. Ndoro, A. Mumma, \& G. Abungu (Eds.), Cultural Heritage and the law, protecting immovable heritage in english speaking countries of sub-saharan Africa (pp. 53-62). ICCROM

Neumann, J. E., Yohe, G., Nicholls, R., \& Manion, M. (2000). Sea level rise and global climate change: a review of impacts to US coasts prepared for the pew centre on global climate change.

Oteng-Ababio, M., Owusu, K., \& Appeaning-Addo, K. (2011). The vulnerable state of the Ghana coast: The case of Faana-Bortianor. JAMBA: Journal of Disaster Risk Studies, 3(2), 429-440.

Posnansky, M. (2006). Appreciating the global dimension of Ghana's past. Transactions of the Historical society of Africa, 10(new series), 49-63.

Revkin, A. C. (2015, November 6). The reality gap in the push to close the global warming emissions gap in Paris. Retrieved from dotearth. blogs.nytimes.com Dot Earth NewYork Times Blog website: http:// dotearth.blogs.nytimes.comthe-reality-gap-in-the-push-to-close-theglobal-warming-emissions-gap-in-paris/?_r $=0$.

Rockman, M. (2015). An NPS framework for addressing climate change with cultural resources. The George Wright Forum, 32(1), 38-43.

Rockman, M.(2012). The necessary roles of archaeology in climate change mitigation and adaptation. In M. Rockman \& J. Flatman (Eds.), Archaeology in society: Its relevance in the modern world (pp.193215). New York: Springer-Verlag.

Rudiak-Gould, P. (2011). Climate change and Anthropology: The importance of Reception Studies. Anthropology Today 27(2), 9-12. Retrieved from http://www.therai.org.uk/at/debate

Sagoe-Addy, K., \& Addo, K. A. (2012). Effect of predicted sea level rise on tourism facilities along Ghanas Accra Coast. Journal of Coastal Conservation, 17(1), 155-166.

Smith, B. D., \& Zeder, M. A. (2013). The onset of the Anthro pocene. Anthropocene(4), 8-13.

South, S. A. (1977). Method and Theory in Historical Archaeology (1st ed.). NewYork: Academic Press.

Strauss, S. (2009). Global models,local risks:Responding to climate change in Swiss Alps. In S. A. Crate, \& M. Nuttal (Eds.), Anthropology and Climate Change:From encounters to actions (pp. 166-174). London\&NewYork: Routledge Taylor \& Francis.

United Nations Project. (2016, November 3). UNEP Document Repositiry. Retrieved from wedocs.unep.org: http://hdl.handle.net/20.50.1182/7476 


\section{Figures}

Figure 1: Map of Ada Foah, research area

Figure 2: A $20^{\text {th }}$ entury topographic map of the Ada Foah coastline. Note the red pointer marking the fort's original location. The remaining area leading from the south up to that marker has been eroded by the ocean (Map source: Dredging, Environmental and Marine Engineering)

Figure 3: Surface scatter of historical materials on the site

Figure 4: Map of the work area

Figure 5: View of south wall of unit one. Note the dark midden feature in wall

Figure 6: Unearthing the midden feature

Figure 7: Juxtaposition of wall profiles of the trench, to reveal outline of the midden: the south- west quadrant of unit one and south-eastern quadrant of unit two

Legend for Figure 7

\begin{tabular}{|l|l|}
\hline $\mathrm{Y}$ & Midden with metal outline \\
\hline $\mathrm{X}$ & Sterile area \\
\hline $\mathrm{Z}$ & Sandy loose soil \\
\hline
\end{tabular}

Figure 8: Photo of white ware with spatter and sponged decorations

Figure 9: Photo of ginger beer bottle

Figure 10: Profile of vertically everted rim of a shallow bowl

Figure 11: Photo of smoking pipes

Figure 12: Photo of white wares with cut sponged decorations and spatter

Figure 13: Dutch case gin bottle 